\title{
Mniejszości narodowe w świetle teoretycznej refleksji polityczno-prawnej
}

\begin{abstract}
Dlatego też ochrona przed tyranią urzędnika nie wystarcza; potrzebna jest także ochrona przed tyrania panującej opinii i nastroju; przed skłonnością społeczeństwa do narzucania za pomoca innych środków niż kary prawne swoich własnych idei i praktyk jako reguł postępowania tym, którzy się z nimi nie godzą; do krępowania rozwoju lub, jeśli można, zapobiegania powstaniu jakiejkolwiek indywidualności nie stosującej się do jego zwyczajów oraz do zmuszania wszystkich charakterów, aby się kształtowały na jego modłę ${ }^{1}$.
\end{abstract}

Pojęcie mniejszości narodowych stanowi interdyscyplinarny obiekt zainteresowań naukowych m.in. politologów, socjologów, kulturoznawców, filozofów polityki, jak i prawników. Wśród przedstawicieli tej ostatniej grupy badaczy dostrzec można, iż problematyka ta wzbudza odmienną refleksję u dogmatyków prawa konstytucyjnego niż u tych, którzy zajmuja się prawem międzynarodowym. Co istotne, pojęcie mniejszości narodowych mieści się także w zakresie badań teoretyków doktryn polityczno-prawnych i nie stanowi ono jedynie pewnego waskiego tematu badawczego, ale dotyka swoim zakresem licznych odmiennych zagadnien, takich jak wielokulturowość, procesy globalizacyjne i powiązane $\mathrm{z}$ tym ideologie antyglobalizacyjne, prawo samostanowienia oraz suwerenności ludów, i w końcu zagadnień zaliczanych do zakresu problematyki funkcjonowania demokracji.

Celem niniejszego artykułu jest próba usystematyzowania pewnych konstrukcji teoretycznych służących wyjaśnieniu zjawisk dotyczących statusu mniejszości narodowych oraz ich funkcjonowania w ramach

\footnotetext{
${ }^{1}$ J.S. Mill, Utylitaryzm. O wolności, Warszawa 2005, s. 97.
} 
normatywnego porządku prawnego opartego na określonych ideologiach i wartościach. Dla klarowności oraz usystematyzowania tegoż wywodu pragnę postawić i udowodnić tezę, iż status mniejszości narodowych jest najlepiej zagwarantowany w państwach, w których obywatelstwo wynika z tzw. domniemanej zgody pod warunkiem, iż prowadzą one politykę wielokulturowości. Aby udowodnić przedstawiona powyżej tezę, zostanie zaprezentowana analiza trzech zagadnień. Najpierw obiektem zainteresowania będzie problematyka źródeł obywatelstwa, w szczególności konfrontacja teoretycznych modeli opartych na zasadzie domniemanego pochodzenia członków wspólnoty oraz domniemanej ich zgody. Następnie przedstawiona zostanie ideologia wielokulturowości, operująca argumentacją, która służy obronie silnej pozycji mniejszości narodowych. Na koniec przybliżony zostanie stosunek państw liberalnych demokracji zarówno wobec samych mniejszości narodowych, jak i teorii wielokulturowości.

Warto na wstępie zaznaczyć, iż samo pojęcie etniczności wiąże się bezpośrednio z zagadnieniami narodowości oraz nacjonalizmu ${ }^{2}$. Termin ten jest wiec bezpośrednio pochodna zasady powszechnej suwerenności narodu, której fundament stanowi zgodność i jednolitość społeczna określająca tożsamość zbiorową obywateli. Dlatego zagadnienie mniejszości narodowych jako podmiotów, które co najmniej potencjalnie mogą zakłócić harmonię polityczną oraz terytorialną państwa, stało się niezwykle istotnym punktem rozważań nie tylko polityków, lecz i teoretyków.

\section{Źródła obywatelstwa: domniemane pochodzenie i domniemana zgoda}

Na potrzeby prezentowanego wywodu odwołam się do przedstawionego przez Jennifer Jackson Preece podziału wspólnot politycznych na wspólnoty domniemanego pochodzenia oraz wspólnoty domniemanej zgody $^{3}$. Podział ten jest oczywiście konstrukcją metodologiczną oparta na typach idealnych, co oznacza, iż cechy opisane w każdym modelu są szczególnie wyraziste, aby móc precyzyjniej wytłumaczyć zachodzące $\mathrm{w}$ nim relacje i zasadę funkcjonowania. W rzeczywistości nie występuja

\footnotetext{
${ }^{2}$ Pojęcie narodu nie jest jednoznaczne. Przykładowo, dla Amerykanów jest ono tożsame z terminem „społeczeństwo”, natomiast w Europie może odnosić się zarówno do wspólnoty kulturowej, jak i etnicznej; szerzej: J.P. Hudzik, Wyktady z filozofii polityki, Lublin 2002, s. 150-151.

${ }^{3}$ J.J. Preece, Prawa mniejszości, Warszawa 2007, s. 166.
} 
żadne wspólnoty polityczne, które byłyby zgodne tylko z jednym typem, jednocześnie nie posiadając cech charakterystycznych dla drugiego.

Wspólnota domniemanego pochodzenia oparta jest na istniejących pomiędzy jej członkami więziach pokrewieństwa lub krwi. Faktyczne biologiczne podobieństwo nie jest jednak istotne, gdyż podstawą ideologicznej tożsamości jest mit wspólnego pochodzenia, z którego wynika siła więzi społecznych, czyli także politycznych ${ }^{4}$. Istotne są natomiast cechy etniczne członków wspólnoty, takie jak określony sposób ubioru, dialekt czy zwyczaje. Stanowia one postrzegalny dowód na istnienie domniemanego pokrewieństwa. Grupy takie maja charakter ekskluzywny, a możliwość przyłączenia się do nich dla osób pochodzacych z zewnątrz jest wyjątkowo trudna, jeśli w ogóle możliwa. Prowadzi to wniosku, iż przynależność narodowa jest elementem tożsamości całej organizacji społecznej5.

Przeciwieństwem przedstawionego modelu jest wspólnota domniemanej zgody, w której relacje wewnątrzwspólnotowe oparte sa na określonym prawie czy przysiędze. Również w tym typie nie jest istotna historyczna ciagłość i prawdziwość domniemanej zgody, ponieważ podstawa ideologicznej tożsamości członków wspólnoty jest mit zgody. Dlatego ten model organizacji społecznej jest silnie inkluzyjny, a cechy, takie jak podobny ubiór czy wspólny dialekt, służa jedynie jako wyznacznik, kto należy do grupy. Przystapienie do wspólnoty ograniczone jest jedynie do uznania warunków umowy powszechnie akceptowanych przez cała grupę. Wynika z tego, że przynależność narodowa jest jedynie cechą pochodną i fakultatywną tożsamości społecznej ${ }^{6}$.

Bez watpienia zagadnienie to sięga do jednej z najważniejszych klasyfikacji doktryn polityczno-prawnych, rozróżniajacej doktryny holistyczne i kontraktualne ${ }^{7}$. Pierwsze z wymienionych głoszą, iż panstwo jest bytem naturalnym, a człowiek jako istota niesamowystarczalna posiada charakter społeczny i żyje w styczności z innymi ludźmi, co pozwala mu na zaspokojenie wszystkich jego potrzeb. Tradycja takiego myślenia wywodzi sie już od Arystotelesa, a została rozpropagowana w późnym średniowieczu dzięki recepcji Stagiryty dokonanej przez św. Tomasza z Akwinu ${ }^{8}$. Drugi wymieniony rodzaj doktryn

${ }^{4}$ Szerzej: T. Biernat, Mit polityczny, Warszawa 1989.

${ }^{5}$ J.J. Preece, Prawa..., s. 167.

${ }^{6}$ Ibidem, s. 168.

${ }^{7}$ Szerzej: Z. Rau, Contractarianism versus Holism. Reinterpreting Locke's Two Treaties of Government, London 1995.

${ }^{8}$ J. Sieroń, Status jednostki i państwa $w$ greckiej $\pi o ́ \lambda l \varsigma ~ w$ świetle filozofii Sokratesa, Platona i Arystotelesa, Katowice 2003, s. 161-253; A. MacIntyre, Krótka historia etyki, Warszawa 2002, s. 163-166. 
operuje teoretyczna koncepcją umowy społecznej, która oparta na indywidualizmie metodologicznym zakłada, iż państwo, społeczeństwo i prawo sa konwencjonalnym produktem świadomej kreacji, dokonanej przez chronologicznie pierwotne jednostki. Człowiek, zawierając umowe społeczna z innymi jednostkami, kształtuje tak państwo, aby odpowiadało ono jego potrzebom ${ }^{9}$. Pomimo występowania pewnych elementów kontraktualnych już nawet w starożytnej Grecji, uznaje się jednak, iż doktryny te powstały w XVII w., a za ich czołowych przedstawicieli należy uznać m.in.: Johna Locke`a, Tomasza Hobbesa oraz Jana Jakuba Rousseau ${ }^{10}$.

Hans Kohn wprowadził rozróżnienie na narody etniczne odpowiadajace wspólnotom domniemanego pochodzenia oraz narody obywatelskie, bliższe wspólnotom domniemanej zgody ${ }^{11}$. Kluczowe dla tego podziału jest pojęcie obywatelstwa, które może być oparte albo na zasadzie ius sanguinis, albo ius solis. Dychotomia ta także operuje na typach idealnych. W państwach, które nadaja obywatelstwo na zasadzie prawa krwi, decydujacym czynnikiem odpowiedzialnym za otrzymanie rzeczonego statusu jest oczywiście pochodzenie, czyli możliwość wykazania ciągłej linii swoich przodków aż do obywateli danego narodu. Miejsce urodzenia pozostaje w tej kwestii bez znaczenia. Takie państwa ułatwiaja uzyskanie obywatelstwa osobom posiadajacym właściwe etniczne pochodzenie, czyli takim, które urodziły się za granica, jednocześnie uniemożliwiając uzyskanie statusu naturalizowanego obywatela tym, którzy przyszli na świat na terytorium państwa i nawet długo tu zamieszkiwali, nie mając jednak wymaganych więzi krwi ${ }^{12}$. Klasycznym przykładem takiego państwa była Republika Federalna Niemiec, w której długo obowiązywało ustawodawstwo z 1913 r. wymagajace dziedziczenia obywatelstwa. Uniemożliwiało to uzyskanie obywatelstwa niemieckiego mniejszościom narodowym polskim i żydowskim, które zamieszkiwały wcześniej Cesarska Rzeszę. Przeciwieństwem opisanej reguły otrzymywania obywatelstwa jest zasada głoszaca, iż człowiek uzyskuje ten status prawny ze względu na miejsce swojego urodzenia, czyli w zależności od terytorium, na którym znajdował sie w chwili narodzin. Osoby urodzone poza granicami moga jednak otrzymać tzw. naturalizowane obywatelstwo, jeśli spełnią przewidziane prawem warunki.

${ }^{9}$ J. Hampton, Umowa i zgoda, [w:] R. E. Goodin, F. Pettit, Przewodnik po wspótczesnej filozofii politycznej, Warszawa 2002, s. 489-507.

${ }^{10}$ Szerzej: Z. Rau, M. Chmieliński (red.), Umowa spoteczna i jej krytycy $w$ myśli politycznej i prawnej, Warszawa 2010.

${ }^{11}$ Szerzej: H. Kohn, The Idea of Nationalism, New York 1960.

${ }^{12}$ Szerzej: ibdem; E. Gelner, Narody i nacjonalizm, Warszawa 1991. 
Kolejnym etapem rozważań jest poddanie analizie różnic występujacych pomiędzy obywatelskimi a etnicznymi państwami narodowymi. Doskonałym przykładem pierwszego wymienionego państwa sa Stany Zjednoczone, w których twórcy konstytucji jak Waszyngton, Jefferson czy Madison nazywani są „ojcami założycielami” ${ }^{13}$. Już samo to określenie wyjątkowo wyraziście obrazuje, iż tożsamość narodowa Amerykanów oparta jest na zasadzie obywatelstwa, rozumianego jako wspólne doświadczenie polityczne wsparte o gwarancje konstytucyjne przynależne każdemu bez względu na jego etniczne pochodzenie (z wyjatkiem specyficznej roli Afroamerykanów) ${ }^{14}$. Taki typ państwa, w którym etniczność jest sprowadzona wyłącznie do sfery życia prywatnego, a nie publicznego, sprzyja istnieniu mniejszości narodowych ${ }^{15}$. Kultywowanie tradycji, języka czy ubioru przez członków tychże mniejszości jest dozwolone w ich prywatnych domach, o ile nie stanowi to bezpośrednio zagrożenia dla tożsamości i bezpieczeństwa narodowego. Państwo zatem w sferze publicznej aktywnie promuje tylko jedna kulturę i język, posługując się polityka paternalistyczną oraz asymilacyjna, służąca najczęściej wychowaniu tak samo równych i wolnych obywateli, co przykładowo w kulturze anglosaskiej sprowadzało się do wzorca białych, heteroseksualnych mężczyzn protestanckiego wyznania ${ }^{16}$. Wynika z tego, że obywatelskie państwa narodowe moga więc wprowadzać pewne ograniczenia względem mniejszości narodowych.

Etniczne państwa narodowe, charakteryzujące się cechami wspólnoty pokrewieństwa, pozbawiaja tym samym jednostkę możliwości decydowania o swoim obywatelstwie. Człowiek jest więc niejako od poczecia predestynowany do posiadania obywatelstwa lub niemożliwości jego zdobycia. Etniczne państwa narodowe sa z reguły wrogo nastawione wobec mniejszości narodowych. Warto natomiast wspomnieć, iż tendencje nacjonalistyczne występujące wśród obywateli tych państw służyły pierwotnie w XIX stuleciu jako motywacja do scalenia narodów znajdujących się pod rządami różnych monarchii dynastycznych ${ }^{17}$. Ideologicznie przysłużył się także do tego wspomniany już mit domniemanego wspólnego pochodzenia, który stał się orężem nacjonalizmu uznającego wyższość interesu zbiorowego całego narodu nad wolnością i prawami jednostki. Historyczny rozwój tej idei spowodował jeszcze dalej idące transformacje doktrynalne. Argumentacja podkreślająca

${ }^{13}$ J. Wróblewski, Konstytucja USA 1787-1987. Historia i wspótczesność, Warszawa 1987, s. 333 .

${ }^{14}$ J.J. Preece, Prawa..., s. 180.

${ }^{15}$ T. Buksiński, Wspótczesne filozofie polityki, Poznań 2006, s. 356.

${ }^{16}$ A. Szahaj, M.N. Jakubowski, Filozofia polityki, Warszawa 2005, s. 170.

${ }^{17}$ J.J. Preece, Prawa..., s. 183. 
jedność narodu, która stanowiła fundament tendencji zjednoczeniowych w dążeniu do odzyskania suwerenności narodu, doprowadziła w skrajnych przypadkach do wytworzenia się wyjatkowo zbrodniczych doktryn, takich jak faszyzm i nazizm, które uzasadniały w imię narodowej więzi krwi wypędzania, osadzanie w gettach oraz eksterminacje mniejszości narodowych ${ }^{18}$. Jak napisała J.J. Preece: „Założeniem stojącym za wszystkimi z powyższych reakcji jest to, że stabilność polityczna w etnicznym państwie narodowym nie może tolerować różnorodności etnicznej, gdyż takie podziały osłabiają integralność panującego porządku politycznego poprzez kwestionowanie problemu mitu wspólnego pochodzenia, na którym się opiera" ${ }^{19}$. Dlatego państwo narodowe obojętnie czy obywatelskie, czy etniczne powinno posiadać jedna tożsamość społeczna, wspólną dla wszystkich obywateli. Socjotechniczne metody i strategie budowania narodu pozwalaja na wytworzenie homogenicznego społeczeństwa, które jest łatwiejsze do rządzenia ${ }^{20}$. W przypadku bardziej liberalnych państw narodowych, które dopuszczaja pluralizm kultowy i etniczny w życiu społecznym, moga występować określone gwarancje konstytucyjne, uznające tylko jedną narodowość lub nadające uprawnienia polityczne tylko konkretnemu elektoratowi.

\section{Wielokulturowość (multikulturalizm² ${ }^{21}$ jako ideologia broniąca praw mniejszości narodowych}

Państwa wielokulturowe to takie, które charakteryzują się tym, że są wspólnotami opartymi na zgodzie, a nie pochodzeniu. Różnią się jednak tym od obywatelskich państw narodowych, iż sferę etniczności nie ograniczaja tylko i wyłacznie do wymiaru prywatnego życia jednostek, ale oficjalnie popiera się i uznaje różnorodność kultury, religii i języka wśród wszystkich członków społeczeństwa ${ }^{22}$. W ten sposób tożsamość mniejszości narodowych zostaje wprowadzona także na płaszczyznę życia publicznego. Warunkiem istnienia tak szerokiego pluralizmu społecznego jest określenie zasad życia publicznego, które będą akceptowalne

${ }^{18}$ Szerzej: T. Filipiak, Polityczna i społeczna doktryna faszyzmu, Warszawa 1985.

19 J.J. Preece, Prawa..., s. 187.

${ }^{20}$ W. Kymlicka, Wspótczesna filozofa polityczna, Warszawa 2009, s. 399.

${ }^{21}$ Pojęcie wielokulturowości i multikulturalizmu sa ze sobą tożsame i bywaja zamiennie używane w literaturze przedmiotu. Różnica wydaje się wynikać $\mathrm{z}$ odmiennego tłumaczenia anglojęzycznej formy multiculturalism. Ze względów językowych właściwszy wydaje się termin „wielokulturowość”. Ponadto można spotkać się z takimi określeniami, jak „polityka uznania”, „polityka tożsamości”, „polityka różnicy”.

${ }^{22}$ A. Heywood, Politologia, Warszawa 2006, s. 149-150. 
dla wszystkich mniejszości. Aby uzyskać takie uznanie polityczne, nie zagrażające jednocześnie trwałości istnienia państwa, należy zadbać, aby status obywatelski wszystkich ludzi był identyczny. Konieczne jest, by istniały nie tylko gwarancje sprowadzające się do zachowania własnej kultury przed asymilację $\mathrm{z}$ większością społeczną, ale także należy zapewnić możliwość promowania tożsamości przez mniejszości narodowe ${ }^{23}$.

$\mathrm{Na}$ płaszczyźnie instytucjonalnej przejawami wielokulturowości sa takie regulacje prawne, które wprowadzaja autonomię organizacji mniejszości, podział władzy, jak i reprezentacje proporcjonalna ${ }^{24}$. Ten ostatni element był już opisany w XIX w. przez Johna Stuarta Milla jako remedium dla ustrojów demokratycznych chroniące przed niebezpieczeństwem realizacji woli większości ${ }^{25}$. Zyskanie przychylności obywateli należących do mniejszości prowadzi do wzrostu ich aktywności w życiu publicznym. Dlatego teoretycy idei wielokulturowości operują terminem „zróżnicowanego obywatelstwa”, które stanowi rewizję klasycznej koncepcji obywatelstwa i sprowadza się do uznania, iż członkom mniejszości narodowych przysługuja nie tylko prawa i wolności wynikające $\mathrm{z}$ racji bycia człowiekiem, ale ponadto i takie, które wiążą się z przynależnością do określonej grupy etnicznej ${ }^{26}$. Prawa te w szczególności dotycza politycznej partycypacji i moga przybrać postać obniżenia progu wyborczego dla danych mniejszości narodowych lub zapewnienia określonej liczby mandatów podczas przeprowadzania wyborów do ciał przedstawicielskich, a w szczególności do parlamentu. W ten sposób polityka „zróżnicowanego obywatelstwa” służy afirmacji różnic istniejących pomiędzy grupami narodowościowymi ${ }^{27}$.

Istotną rolę w polityce wielokulturowości odgrywa także polityka kulturowa i edukacyjna, majaca na celu poznanie, zrozumienie i akceptację tożsamości kulturowej mniejszości narodowych ${ }^{28}$. Na podstawie

${ }^{23}$ S. White, Równość, Warszawa 2008, s. 172.

${ }^{24}$ Szerzej: G. Sartori, Teoria demokracji, Warszawa 1994.

${ }^{25} \mathrm{Z}$. Rau, Liberalizm; zarys myśli politycznej XIX i XX wieku, Warszawa 2000, s. 66-85; szerzej J.S. Mill, Utylitaryzm...; idem, O rzadzie reprezentatywnym, Kraków 1995.

${ }^{26}$ I.M. Young, Polity and Group Difference: A Critique of the Ideal of Universal Citizenship, „Ethics” 1989, no. 99/2, Chicago, s. 250-274.

${ }^{27}$ W. Kymlicka, Wspótczesna..., s. 405.

${ }^{28}$ Szerzej o ideologii wielokulturowości patrz: M. Walzer, Interpretacja i krytyka społeczna, Warszawa 2002; J. Carens, Cuture, Citizenship and Community, Oxford 2000; J. Levy, Multiculturalism of fear, Oxford 2000; B. Parekh, Rethinking Multiculturalism: Cultural Diversity and Political Theory, Harvard 2000; J. Tullly, Strange Multiplicity: Constitutionalism in the Age of Diversity, Cambridge 1995; A. Gutmann (ed.), Multiculturalism and the "Politics of Recognition", Princeton 1992; W. Kymlicka, Multicultural Citizenship, Oxford 1995; J. Raz, The Morality of Freedom, Oxford 1986. 
zaprezentowanego opisu można uznać, iż ideałem teorii wielokulturowości jest społeczeństwo, składające się z różniących się pod względem etnicznym wspólnot, których członkowie jednak podzielają poczucie przynależności do nadrzędnej jednoczącej wszystkich metawspólnoty politycznej opartej i promującej prawa i wolności człowieka ${ }^{29}$.

W sensie filozoficznym wielokulturowość można określić za T. Buksińskiem jako „swoisty relatywizm kulturowy waloryzujacy pozytywne partykularności”30. Według tej ideologii cechy jednostki są uwarunkowane kulturowo, z czego wynika, iż indywidualne dążenia każdego człowieka wpływające na jego poczucie własnej godności sa zdeterminowane kultura, w jakiej został wychowany ${ }^{31}$. Jak słusznie zauważył Will Kymlicka: „Ogólnie rzecz biorąc, rodzimy język i kulturę należy postrzegać nie jako obiekty dobrowolnego wyboru, lecz jako okoliczności, na które nie mamy wpływu" ${ }^{32}$. W tym ujęciu jednostka jest postrzegana jako podmiot zdeterminowany praktykami społecznymi, co pozwala na wyciagnięcie wniosku, iż interes całej wspólnoty, jak i istniejących w ramach jej mniejszości, nie może być sprowadzony tylko do sumy interesów indywidualnych ${ }^{33}$. Dlatego każda kultura narodowa jest wyjatkowa i niepowtarzalna niczym „Duch Praw” u Monteskiusza ${ }^{34}$. Ten relatywizm kulturowy wymusza zatem warunek pluralizmu w relacjach pomiędzy członkami odmiennych narodowości i prowadzi do uznania wszystkich kultur jako równowartościowych ${ }^{35}$. Dlatego pojęciem wielokulturowości określa się także społeczno-polityczne strategie mające na celu rozpoznanie i ochronę kultur mniejszości ${ }^{36}$.

Przywołany pluralizm wartości nie jest jednak idea wynaleziona przez filozofów wielokulturowości, ponieważ termin ten stanowił jeden z filarów doktryny Isaiaha Berlina ${ }^{37}$. Pisał on bowiem, że: „Jeśli każda kultura wyraża swoją własna wizję - i ma do tego prawo - i jeśli cele i wartości różnych społeczeństw oraz sposobów życia sa niewspółmierne, wynika z tego, iż nie ma jednego zbioru zasad, żadnej uniwersalnej

${ }^{29}$ A. Szahaj, M. N. Jakubowski, Filozofia..., s. 173.

${ }^{30}$ T. Buksiński, Wspótczesne filozofie..., s. 355.

${ }^{31}$ B. Pasamonik, Znaczenie wspólnoty w procesie budowy tożsamości osobowej, [w:] M.N. Jakubowski, A. Szahaj, K. Abriszewski (red.), Indywidualizm, wspólnotowość, polityka, Toruń 2002, s. 109-123.

${ }^{32}$ W. Kymlicka, Wspóczesna..., s. 411

${ }^{33}$ P. Kelly, Liberalizm, Warszawa 2007, s. 177-178; W. Kymlicka, Wspóczesna..., s. 408.

${ }^{34}$ Szerzej: K. Monteskiusz, O duchu praw, Warszawa 2002.

${ }^{35}$ Szerzej: Ch. Taylor, Multiculturalism and "The Politics of Recognition", Princeton 2000.

${ }^{36}$ S. White, Równość, s. 171.

${ }^{37}$ J. Gray, Liberalizm, Kraków 1994, s. 53; Z. Rau, Liberalizm..., s. 117-121. 
prawdy dla wszystkich ludzi zawsze i wszędzie" ${ }^{38}$. Występował zatem przeciwko wierze $\mathrm{w}$ istnienie jednego uniwersalnego i obiektywnego systemu wartości, promując jednocześnie relatywizm wartości, który jego zdaniem służył każdej jednostce w celu autonomicznego wyboru realizacji swojej wolności indywidualnej.

Należy pamiętać, iż zagadnienie wielokulturowości wyrasta swym zakresem poza problematykę mniejszości kulturowych. W. Kymlicka zaliczył także do tego zagadnienia sytuację: primo imigrantów zarówno ekonomicznych, jak i politycznych, którzy dysponują możliwością nabycia obywatelstwa, secundo migrantów nielegalnych i czasowych, czyli jednostek, które nie sa traktowane jako obywatele i którym nie dane będzie nigdy uzyskać prawnego statusu obywateli (określani przez Michaela Walzera jako „metojkowie”, co stanowi odwołanie do starożytnej Grecji i ówczesnej grupy rezydentów, czyli wolnych ludzi bez praw obywatelskich ${ }^{39}$ ), tertio izolacjonistycznych grup etniczno-religijnych, określanych w literaturze przedmiotu mianem „obywateli częściowych" ${ }^{40}$, gdyż dobrowolnie rezygnują oni z określonych praw i wolności demokratycznego obywatelstwa przykładowo jak amisze, chasydzi, hutteryci; oraz quatro Afroamerykanów, którzy stanowią kategorię sui generis, gdyż żyją w Stanach Zjednoczonych równie długo jak biała ludność, chociaż nie mogli długo otrzymać obywatelstwa, a jednocześnie nie posiadali jednolitej kultury i języka ${ }^{41}$.

Pomimo skrupulatnej i bardzo dobrze odebranej w literaturze przedmiotu analizy problematyki wielokulturowości, W. Kymlicka niedostatecznie wyczerpujacco opracował najważniejszą z grup - od której zresztą rozpoczął swój wywód - czyli mniejszości narodowe. Zdefiniował je jako: „grupy, które na swoim historycznym terytorium stworzyły pełne, funkcjonalne społeczeństwa, które zostały następnie wcielone do większego organizmu państwowego". Dokonał klasyfikacji mniejszości narodowych na narody subpaństwowe oraz ludy rdzenne ${ }^{42}$. Pierwsza grupa dotyczy narodów posiadajacych wcześniej własne terytorium państwowe utracone w trakcie wojny, mariaży dynastycznych lub utworzenia federacji z innym narodem. Termin „ludy rdzenne” odnosi się natomiast do wspólnot, których ziemie zostały zaanektowane przez osadników, a ich członkowie zostali siłowo wcieleni do państwa, pierwotnie

${ }^{38}$ I. Berlin, Pokrzywione drzewo człowieczeństwa, Warszawa 2004, s. 196.

${ }^{39}$ Szerzej: M. Walzer, Sfery sprawiedliwości. Obrona pluralizmu $i$ wolności, Warszawa 2007.

${ }^{40}$ Szerzej: J. Spinner, The Boundaries of Citizenship: Race, Ethnicity, and Nationality in the Liberal State, Baltimore 2000.

${ }^{41}$ W. Kymlicka, Wspótczesna..., s. 420-439.

${ }^{42}$ Ibidem, s. 421-425. 
dla nich obcego. Innymi słowy, narody subpaństwowe przegrały walce o uzyskanie suwerenności (Katalończycy, Baskowie, Flamandczycy, Szkoci, Walijczycy Portorykańczycy czy francuskojęzyczni mieszkańcy Quebecu) w przeciwieństwie do ludów rdzennych pozostających we wcześniejszej izolacji wobec cywilizacji osadników (Inuici, Maorysi czy Indianie amerykańscy).

Przedstawiona klasyfikacja pomija sytuacje mniejszości narodowych zamieszkujacych obecnie obce kraje w wyniku traktatowych ustaleń związanych z zakończeniem II wojny światowej, a których ojczyzna znajduje się obecnie poza granicami historycznie pierwotnymi. Mniejszości takie jak choćby Polacy na Wschodzie znajdują się w zupełnie odmiennej sytuacji geopolitycznej niż przywołane narody subpaństwowe lub ludy rdzenne. Posiadają one teoretyczną możliwość powrotu do ojczyzny, jednak realizacja tej decyzji byłaby okupiona utrata majatku zazwyczaj dziedziczonego od wielu pokoleń. Członkowie takich wspólnot są zatem w wyjątkowo trudnym położeniu. Z jednej strony ich walka z utrata narodowej tożsamości i asymilacją z państwem, w którym przyszło im obecnie żyć, wytworzyła u nich silne poczucie patriotyzmu, nostalgii i tęsknoty za ojczyzną. Paradoksalnie uczucia patriotyczne moga okazać się znacznie intensywniejsze aniżeli u rodaków żyjących w ojczyźnie, nominalnie uznającej pluralizm wartości i światopoglądów. Członkowie tych mniejszości pozostaja jednak w dużej mierze związani z obecnym miejscem zamieszkania poprzez liczne układy personalne, zawodowe czy finansowe. Całokształt sytuacji komplikuje ponadto uwikłanie polityczne tychże mniejszości. Ich status jest bowiem zależny od realnej polityki międzynarodowej, a w szczególności relacji pomiędzy krajem zamieszkania a państwem ojczystym ${ }^{43}$.

\section{Stosunek państw liberalnych demokracji do mniejszości politycznych i idei wielokulturowości}

W XVIII i XIX w. liczne kraje stosowały różne środki majace na celu zarówno odebranie mniejszościom narodowym władzy politycznej, jak i wynarodowienie, czyli utrate poczucia własnej odrębnej tożsamości narodowej. Uzasadnieniem takich działań była obawa przed tendencjami separatystycznymi oraz brakiem lojalności wobec państwa. W przypadku ludów rdzennych dochodził jeszcze argument o wyższości cywilizacyjnej osadników i paternalistycznej funkcji przysposobienia

${ }^{43}$ Szerzej: D. Górecki (red.), Sytuacja ludności polskiej na Wschodzie w świetle obowiazujacego prawa i praktyki, Torun 2009. 
tubylców do życia w znajdującym się na wyższym etapie rozwoju społeczeństwie dla ich własnego dobra, co jednoznacznie wzbudza skojarzenia z wyznawana przez J.J. Rousseau "wola powszechna”" ${ }^{4}$. Sytuacja ta odmieniła się w XX w. na skutek porażki podejmowanych działań. Walka $\mathrm{z}$ trwałością tożsamości mniejszości narodowych była nieskuteczna, a wręcz prowadziła do przeciwnych od założonych rezultatów. Zamiast powodować wzrost lojalności wobec państwa podsycała jedynie wrogość i prowadziła do eskalacji konfliktów. Dwudziestowieczna zmiana optyki postrzegania mniejszości narodowych wynika także z braku obecnie normatywnych uzasadnień walki z mniejszościami narodowymi. Z punktu widzenia prawa międzynarodowego niedopuszczalne sa działania prowadzace do czystek etnicznych, odbierania obywatelstwa czy naruszania praw człowieka. Zaznaczyć zatem należy w tym miejscu, iż w krajach liberalnych demokracji może pojawić sie problem nacjonalizmów mniejszości narodowych, ale z racji, iż zagadnienie to nie jest przedmiotem niniejszego artykułu, nie będzie więc dalej rozwijane.

Na płaszczyźnie teoretycznej zasadnicze pytanie dotyczące mniejszości narodowych sprowadza się do zagadnienia sprawiedliwego prowadzenia polityki przez państwo względem własnych obywateli oraz członków rzeczonych mniejszości. Jest wiec to pytanie, czy obie grupy powinny być traktowane przez państwo jednakowo, czy też któraś z nich powinna być uprzywilejowana, a jeśli tak, to dlaczego i w jakim zakresie? Niektórzy uważają, iż sama idea wielokulturowości łącząca założenie pewnej identyczności a zarazem konkurencyjności kultur jest sama w sobie niemożliwa do realizacji. Jest tylko: „Wyrazem wiary pięknoducha, że kot, mysz i pies moga się najeść z jednej miski” ${ }^{45}$. W tym ujęciu wielokulturowość pozostaje więc tylko doktryną na płaszczyźnie formalnych deklaracji i nominalnych uprawnień, które nie zmieniaja realnych stosunków i relacji społecznych. Inni krytycy wielokulturowości sądzą, iż sprawiedliwość powinna być „ślepa na kolory”, co oznacza, iż nie można kategoryzować i wartościować obywateli ze względu na pochodzenie etniczne ${ }^{46}$. Odmienną argumentacją jest pogląd, głoszący, iż wielokulturowość stanowi zagrożenie dla jednolitości i stabilności społecznej i politycznej. Inaczej jednak niż w poprzednich stuleciach rozłożony jest merytoryczny akcent tego argumentu; niegdyś odmawiano mniejszościom praw, bojąc się o secesję; dziś podnosi się obawę o tworzenie niepotrzebnych podziałów, które „upolityczniaja etniczność”.

${ }^{44}$ J.J. Rousseau, Umowa społeczna, Warszawa 1966.

${ }^{45}$ U. Beck, Wtadza i przeciwwtadza $w$ epoce globalnej. Nowa ekonomia polityki światowej, Warszawa 2005.

${ }^{46}$ W. Kymlicka, Współczesna..., s. 441. 
Takie stanowisko występuje w dyskursie liberałów z komunitarystami w kontekście zanikania cnót obywatelskich w demokracjach liberalnych ${ }^{47}$. W tym ujęciu wielokulturowość jest dodatkowym czynnikiem osłabiającym więzy solidaryzmu społecznego i niezależnie jak definiowanego pojęcia dobra wspólnego. Wszakże, jak wiemy z lektury art. 1 Konstytucji Rzeczypospolitej Polskiej, res publica res populi est.

Kolejną wątpliwość budzi problematyka publicznej redystrybucji, czyli aktywnego oddziaływania państwa na wszystkich obywateli celem ograniczenia nierówności ekonomicznych oraz statusu społecznego. Krytycy wielokulturowości podnoszą zarzut, iż podważa ona poparcie dla takiej funkcji państwa. Przeciwnie obrońcy tej ideologii wskazuja na to, iż usunięcie barier społecznych dzielących członków mniejszości politycznych od reszty obywateli wzmocni stabilność polityczną, gdyż umożliwi mniejszościom utożsamienie się z instytucjami politycznymi. Jak napisał W. Kymlicka: „Wielokulturowość jest tak samo politycznie dwuznaczna jak nacjonalizm - na który jest odpowiedzią. Tak jak nacjonalizm może służyć uzasadnieniu gęstej, ekskluzywnej i konserwatywnej formy tożsamości narodowej bądź formy rozrzedzonej, inkluzyjnej i liberalne, podobnie wielokulturowe odpowiedzi na budowanie narodu moga przybierać postać liberalna i konserwatywna"48. Dlatego można postrzegać wielokulturowość w określonych przypadkach jako niebezpieczne nacjonalistyczne zagrożenie dla stabilności państwa, a w innych jako tolerancyjną formułe pluralizmu społecznego harmonizujacego całe społeczeństwo.

Nawet wśród ideologów liberalizmu nie ma jednoznacznej opinii na temat wielokulturowości. Dla niektórych jest to doktryna rozwijająca i uzupełniajaca tradycyjne wolności negatywne stanowiace filar klasycznego liberalizmu. Chociaż można też spotkać się ze stanowiskiem, iż wielokulturowość jest przejawem powrotu do tendencji gloryfikujących tożsamość kolektywną, a przez to ogranicza ona indywidualne prawa i wolności człowieka wyabstrahowanego od jakichkolwiek kulturowych i cywilizacyjnych uwarunkowań ${ }^{49}$. Takie rozumowanie oparte jest na argumentacji, iż skoro w państwie liberalnym nie można narzucić oficjalnej religii, tak i również nie można uznać jakiejkolwiek kultury za uprzywilejowaną w stosunku do pozostałych ${ }^{50}$. Konflikt tych opozycyjnych stano-

${ }^{47}$ S. Czarnecki, Czy liberalizm deprecjonuje wspólnotę? W odpowiedzi na krytykę komunitarystyczna, [w:] M.N. Jakubowski, A. Szahaj, K. Abriszewski (red.), Indywidualizm..., s. 163-176; W. Kymlicka, Liberalizm a komunitarianizm, [w:] P. Śpiewak (red.), Komunitarianie. Wybór tekstów, Warszawa 2004, s. 151-178.

${ }^{48}$ W. Kymlicka, Współczesna..., s. 444.

${ }^{49}$ T. Buksiński, Wspótczesne filozofie..., s. 357; W. Kymlicka, Wspótczesna..., s. 410.

${ }^{50}$ W. Kymlicka, Współczesna..., s. 415. 
wisk bywa też określany w literaturze przedmiotu jako przeciwieństwo nasyconego (thick) i nienasyconego (thin) treścia kosmopolityzmu ${ }^{51}$.

Zbliżając się do końca wywodu, można jeszcze dodać, iż ideologia wielokulturowości jest także obiektem krytyki antyglobalistów ${ }^{52}$. Uważają oni, że doktryna ta poprzez rozbijanie solidarności narodowej i dopuszczanie zachowań wykraczających poza przyjęte kulturowo standardy niszczy państwa narodowe, dając jednocześnie sposobność do panowania globalnym koncernom i korporacjom ${ }^{53}$. Brak jest jednoznacznych danych empirycznych, które pozwoliłyby zakończyć tocząca się od wielu lat dyskusję akademicka nad wpływem efektów teorii wielokulturowości w realnym wymiarze społeczno-politycznym. Nie mniej jednak, w odniesieniu do mniejszości, które nie aspiruja do uzyskania pełni autonomii, przykład Kanady i Australii, jako krajów oficjalnie prowadzących politykę wielokulturowości, wskazuje na uzyskanie pozytywnych skutków ${ }^{54}$.

Konkludując, wielokulturowość jest dla mniejszości narodowych ideologia pozwalającą na utrzymanie wyjątkowości własnej tożsamości kulturowej przy jednoczesnej możliwości realizacji pełni oczekiwań indywidualnych jednostek. Zaspokaja więc oczekiwania zarówno kolektywne, jak i indywidualne członków mniejszości narodowych. Należy jednak pamiętać, iż przedstawiona analiza problematyki ma jedynie charakter teoretyczny, służący pogłębieniu refleksji nad opisem empirycznie weryfikowalnej rzeczywistość mniejszości narodowych.

\section{Bibliografia}

Beck U., Władza i przeciwwtadza w epoce globalnej. Nowa ekonomia polityki światowej, Warszawa 2005.

Berlin I., Pokrzywione drzewo człowieczeństwa, Warszawa 2004.

Biernat T., Mit polityczny, Warszawa 1989.

${ }^{51}$ M. Soniewicka, Granice sprawiedliwości, sprawiedliwość ponad granicami, Warszawa 2010, s. 274-276; szerzej: M. Escamilla, M. Saavedra (eds), Law and Justice In a Global Society, Granada 2005; D.R. Mapel, T. Nardin (eds), International Society: Diverse Ethical Perspectives, Princeton 1998.

${ }^{52}$ T. Buksiński, Współczesne filozofie..., s. 359.

${ }^{53}$ Por. N. Klein, No logo, Warszawa 2009; idem, Mury i wytomy, czyli bariery $i$ szanse. Doniesienia z linii frontu debaty o globalizacji, Warszawa 2008; N. Chomsky, Zysk ponad ludzi: neoliberalizm a tad globalny, Wrocław 2000; Ł. Konsor, Alterglabalizm: charakterystyka idei, Kraków 2005; A. Domosławski, Świat nie na sprzedaż: rozmowy o globalizacji i kontestacji, Warszawa 2002; A. Pomieciński, Alterglobaliści: antropologia ruchu na rzecz globalnej sprawiedliwości, Poznań 2013.

${ }^{54}$ W. Kymlicka, Wspótczesna..., s. 441-442. 
Buksiński T., Współczesne filozofie polityki, Poznań 2006.

Carnes J., Cuture, Citizenship and Community, Oxford 2000.

Chomsky N., Zysk ponad ludzi: neoliberalizm a ład globalny, Wrocław 2000.

Czarnecki S., Czy liberalizm deprecjonuje wspólnotę? Wodpowiedzi na krytykę komunitarystyczna, [w:] M.N. Jakubowski, A. Szahaj, K. Abriszewski (red.), Indywidualizm, wspólnotowość, polityka, Torun 2002.

Domosławski A., Świat nie na sprzedaż: rozmowy o globalizacji i kontestacji, Warszawa 2002.

Escamilla M., Saaverda M. (eds), Law and Justice in a Global Society, Granada 2005.

Filipiak T., Polityczna i społeczna doktryna faszyzmu, Warszawa 1985.

Gelner E., Narody i nacjonalizm, Warszawa 1991.

Górecki D. (red.), Sytuacja ludności polskiej na Wschodzie w świetle obowiazujacego prawa i praktyki, Torun 2009.

Gray J., Liberalizm, Kraków 1994.

Gutman A., Multiculturalism and the „Politics of Recognition”, Princeton 1992.

Hampton J., Umowa i zgoda, [w:] R. E. Goodin, F. Pettit (red.), Przewodnik po wspótczesnej filozofii politycznej, Warszawa 2002.

Heywood A., Politologia, Warszawa 2006.

Hudzik J., Wyktady z filozofii polityki, Lublin 2002.

Kelly P., Liberalizm, Warszawa 2007.

Klein N., Mury $i$ wyłomy, czyli bariery $i$ szanse. Doniesienia $z$ linii frontu debaty o globalizacji, Warszawa 2008.

Klein N., No logo, Warszawa 2009.

Kohn H., The Idea of Nationalism, New York 1960.

Konsor Ł., Alterglobalizm: charakterystyka idei, Kraków 2005.

Kymlicka W., Multicultural Citizenship, Oxford 1995.

Kymlicka W., Wspótczesna filozofia polityczna, Warszawa 2009.

Levy J., Multiculturalism of Fear, Oxford 2000.

MacIntyre A., Krótka historia etyki, Warszawa 2002.

Mapel D.R., Nardin T. (eds), International Society: Diverse Ethical Perspectives, Princeton 1998.

Mill J.S., O rzadzie reprezentatywnym, Kraków 1995.

Mill J.S., Utylitaryzm. O wolności, Warszawa 2005.

Monteskiusz K., O duchu praw, Warszawa 2002.

Parekh B., Rethinking Multiculturalism: Cultural Diversity and Political Theory, Harvard 2000.

Pasmonik B., Znaczenie wspólnoty $w$ procesie budowy tożsamości osobowej, [w:] M.N. Jakubowski, A. Szhaj, K. Arbiszewski (red.), Indywidualizm, wspólnotowość, polityka, Toruń 2002.

Pomieciński A., Alterglobaliści: antropologia ruchu na rzecz globalnej sprawiedliwości, Poznań 2013.

Preece J.J., Prawa mniejszości, Warszawa 2007.

Rau Z., Chmieliński M. (red.), Umowa społeczna i jej krytycy w myśli politycznej i prawnej, Warszawa 2010.

Rau Z., Contractarianism versus Holism. Reinterpreting Locke's Two Treaties of Government, London 1995.

Rau Z., Liberalizm; zarys myśli politycznej XIX $i$ XX wieku, Warszawa 2000.

Raz J., The Morality of Freedom, Oxford 1986.

Rousseau J.J., Umowa spoteczna, Warszawa 1966. 
Sieroń J., Status jednostki $i$ państwa $w$ greckiej $\pi o ́ \lambda ı \varsigma ~ w$ świetle filozofii Sokratesa, Platona i Arystotelesa, Katowice 2003.

Spinner J., The Boundaries of Citizenship: Race, Ethnicity, and Nationality in the Liberal State, Baltimore 2000.

Soniewicka M., Granice sprawiedliwości, sprawiedliwość poza granicami, Warszawa 2010.

Szahaj A., Jakubowski M.N., Filozofia polityki, Warszawa 2005.

Śpiewak P., Komunitarianie. Wybór tekstów, Warszawa 2004.

Taylor Ch., Multiculturalism and „The Politics of Recognition”, Princeton 2000.

Tully J., Strange Multiplicity: Constitutionalism in the Age of Diversity, Cambridge 1995.

Walzer M., Interpretacja i krytyka spoteczna, Warszawa 2002.

Walzer M., Sfery sprawiedliwości. Obrona pluralizmu i wolności, Warszawa 2007.

White S., Równość, Warszawa 2008.

Wróblewski J., Konstytucja USA 1787-1987. Historia i wspótczesność, Warszawa 1987.

Young I. M., Polity and Group Difference: A Critique of the Ideal of Universal Citizenship, „Ethics” 1989, no. 99/2, Chicago. 